\title{
DAMPAK PENGGUNAAN GADGET PADA ANAK USIA DINI (STUDI KASUS DI TK ELEKRINA KERTAPATI PALEMBANG)
}

\author{
Midayana ${ }^{1}$, Dr.Evia Darmawani, M.Pd.Kons², Dessi Andriani, S.Pd,.M.M \\ Email :midayana9@gmail.com¹, evia.syamsudin@gmail.com², \\ Dessiandriani@gmail.com ${ }^{3}$
}

\begin{abstract}
Abstrak : Gadget merupakan suatu teknologi terbaru yang memiliki fungsi tertentu yang berguna bagi manusia untuk mempermudahkan komunikasi, yang menjadi kebutuhan yang harus ada dalam genggaman guna mempermudahkan komunikasi. Pembahasan mengenai komunikasi orang tua terhadap anak dalam mencegah dampak negatif Gadget, bisa diambil kesimpulan tentang pengaruh Gadget terhadap akhlak anak dalam studi kasus di TK Elektrina Kertapati Palembang, Dampak dari tekhnologi khususnya Gadget terhadap pembentukan kepribadian anak antara lain anak akan menjadi lebih pemalas, kurangnya rasa percaya diri pada anak, berkurangnya kemampuan berkomunikasi anak, anak akan lebih tertutup (introvert), ketergantungan anak untuk terus bermain Gadget, dan dampak negatif yang paling berbahaya adalah anak dengan bebas dapat mengakses situs-situs dewasa di internet yang dapat merusak moral anak. Dalam mengatasi ketergantungan Gadget anak orang tua dapat memberikan kesibukan kegiatan kepada anakanya, mengganti Gadget dengan alat bermain tradisisonal, mengajak anak untuk explore alam yang paling penting yaitu orang tua bisa meluangkan waktunya untuk bermain dan berkomunikasi dengan anaknya. Sebagai orang tua yang cerdas, orang tua harus memberikan batasan waktu kepada anaknya untuk bermain Gadget, selalu mendampingi anak saat bermain Gadget, memberikan pengertian tentang dampak positif dan negatif tekhnologi sehingga anak tau mana yang baik dan yang buruk, dan orang tua harus memantau kegiatan anak setiap harinya.
\end{abstract}

Kata kunci : Dampak positif dan negatif gadget

\section{PENDAHULUAN}

Kemajuan teknologi saat ini sangat pesat perkembangan berbagai macam penemuan teknologi modern dengan tujuan mempermudah ruang gerak dan ruang lingkup manusia setiap harinya. Sebagai contoh teknologi yang sangat banyak berkembang pesat pada saat ini adalah telepon. Dimulai dari munculnya telepon koin, telepon genggam (HP), hingga saat sekarang ini orang-orang lebih akrab mengenalnya dengan istilah smartphone atau Gadget .

\section{Perkembangan Gadget dari} masa ke masa dimulai dari perangkat yang bernama HP (Handphone). HP perkembangan dari pesawat elektronik telepon. Bedanya, telepon masih menggunakan kabel untuk berkomukasi sementara HP tanpa perlu menggunakan kabel dan bersifat portable (praktis bisa di bawa kemana-mana) sehingga lebih mempermudahkan manusia untuk berkomunikasi dimanapun dan kapanpun. 
Pada saat ini hampir setiap individu mulai dari anak-anak hingga orang tua kini memiliki handphone atau smartphone. Tentu saja ini bukan hanya terjadi tanpa alasan karena daya tarik dan kebutuhan masyarakat saat ini sudah sangat jauh berbeda dibandingkan beberapa tahun ke belakang. Hp atau Gadget merupakan suatu alat komunikasi yang sangat wajib digunakan oleh orang-orang yang memiliki kepentingan pribadi baik bisnis atau pengerjaan tugas kuliah maupun kantor. Namun kenyataannya pada saat ini Gadget tidak hanya dipakai di kalangan remaja saja yang berusia 12-21 tahun dan dewasa atau lanjut usia yang berusia 22-ke atas, akan tetapi juga dipakai dikalangan usia anak-anak yang ber usia 7-11 tahun. Bahkan lagi Gadget bukan barang asing untuk anak usia dini (usia 3-6 tahun) yang belum layak untuk menggunakan Gadget .

Sesuai dengan perkembangnya gadget pada saat ini memiliki banyak fitur menarik yang seringkali membuat anak-anak cepat akrab dengannya. Akan tetapi dengan perkembangan gadged pada saat ini akan lebih memudahkan anak dalam mencari segala informasi dan berita yang dibutuhkan, terutama dalam belajar sambil bermain ataupun bermain sambil belajar.

Akan tetapi penggunaan Gadget secara berlebihan akan berdampak buruk bagi perilaku anak dalam kesehariannya, karena akan membentuk anak-anak yang cenderung terus-menerus selalu menggunakan Gadget akan sangat ketergantung dan menjadi kegiatan yang wajib dan rutin dilakukan oleh anak dalam aktifitas sehari-hari, dilihat pada saat ini anak lebih sering bermain Gadget dari pada belajar dan berinteraksi dengan lingkungan sekitarnya untuk mendapatkan hal-hal baru. Dari sudut pandang lingkungan masyarakat pada saat ini ada beberapa kasus mengenai dampak dari Gadget ini sering sekali menimpa anak-anak mulai dari kecanduan internet, game, dan juga konten-konten yang berisi pornografi yang nyaris belum di pahami oleh pemakainya.

Berdasarkan dari hasil survei yang telah dilakukan peneliti di TK Elektrina Kertapati Palembang terhadap siswa yang berusia 3-6 tahun, 
ada 76 anak. Diantaranya satu orang anak menggunakan Gadget, yang dibelikan oleh orang tuanya. Adapun dampak yang ditimbulkan dari penggunan Gadget pada anak usia dini ini seperti, penurunan konsentrasi saat belajar (pada saat belajar anak menjadi tidak fokus dan hanya ingin bermain dengan Gadget, sehingga membuat anak akan malas menulis dan membaca, hal ini diakibatkan dari penggunaan Gadget misalnya pada saat anak akan membuka video di aplikasi Youtube anak cendeung melihat gambarnya tanpa harus menulis apa yang mereka cari. Penurunan dalam kemampuan bersosialisasi, misalnya anak kurang bermain dan bersosialisasi dengan dilingkungan sekitarnya, tidak memperdulikan keadaan disekelilingnya. Kecanduan gadget, anak telah ketergantungan dengan Gadget dapat menimbulkan gangguan kesehatan, yang dapat menimbulkan ganggunan kesehatan karena paparan radisasi yang ada pada Gadget, dan juga dapat merusak kesehatan mata anak sehingga mata anak cenderung akan cepat mudah rabun di usinya yang asih terbilang dini. Oleh karena itu peran orangtua seharusnya dapat menyikapi masalah tersebut dengan sangat baik. Dalam kejadian seperti itu tentu saja harus menjadi perhatian bagi orangtua dan berbagai pihak untuk meningkatakan kewaspadaan terhadap anak-anak dalam penggunana Gadget sebagai media bermain atau media komunikasi. Karena pendidikan pertama di dapat dari orang tua terutama ibu yang dalam setiap saatnya bersama dengan anak sehingga dalam pembentukan karakter dan tumbuh kembang anak seharus memiliki dan aturan yang jelas dalam tentang pemberian Gadget pada anak.

Berdasarkan uraian diatas, maka peneliti sanagt tertarik untuk mengkaji tentang apa saja Dampak Penggunaan Gadget Pada Anak Usia Dini (Studi Kasus Di TK Elektrina Kertapati Palembang)

Adapun rumusan masalah di atas yang menjadi pokok dalam penelitian ini merupakan:

1) Bagaimana cara penggunaan Gadget pada anak usia dini di TK Elektrina Kertapati Palembang.

2) Bagaimana dampak positiF dan negatif pada penggunaan Gadget 
pada anak usia dini di TK Elektrina Kertapati Palembang.

3) Bagaimana cara komunikasi orang tua kepada anak dalam mencegah terjadinya dampak negatif Gadget.

Sesuai dengan rumusan masalah tersebut, maka tujuan penelitian ini merupakan:

1) Untuk mengetahui, serta mengkaji dan menganalisis tentang penggunaan Gadget pada anak usia dini di TK Elektrina Kertapati Palembang

2) Untuk mengetahui, serta mengkaji dan menganalisis tentang dampak penggunaan Gadget pada anak usia dini di TK Elektrina Kertapati Palembang.

3) Untuk mengetahui Bagaimana cara komunikasi orang tua kepada anak dalam mencegah terjadinya dampak negatif Gadget.

\section{KAJIAN TEORITIK}

Pendidikan adalah pembelajaran pengetahuan, keterampilan dan kebiasaan sekelompok orang yang di turunkan dari satu generasi ke generasi berikutnya, namun pada saat ini pendidikan menghadapi tantangan besar sebagai akibat dari arus globalisasi, sehingga berbagai upaya perlu dilakukan agar peserta didik kelak mampu mendapatkan kehidupan yang layak di negaranya sendiri ataupun di luar negeri. Pendidikan anak pertama kali diperoleh dari lingkungan keluarga terutama dari kedua orang tuanya. Selanjutnya anak akan berinteraksi dengan lingkungan keduanya yang tidak lain adalah lembaga pendidikan.

Pendidikan Anak Usia Dini adalah pendidikan yang ditujukan kepada anak yang berusia 3 s/d 6 tahun yang ditulis dalam PP No. 27/1990 Pasal 6. Akan tetapi, Undangundang Nomor 20 Tahun 2003 pasal 28 menyatakan bahwa pendidikan anak usia dini diselenggarakan sebelum jenjang pendidikan dasar. Sementara Undang-undang Nomor 23 Tahun 2002 tentang Perlindungan Anak dalam pasal 4 menyatakan bahwa setiap anak berhak untuk hidup, tumbuh, berkembang dan berpartisipasi secara wajar sesuai dengan harkat dan martabat kemanusiaan serta mendapat perlindungan dari kekerasan dan diskriminasi. 
Awal masa kanak-kanak berlangsung dari usia 2-6 tahun, oleh orang tua disebut sebagai usia problematis, Pendidikan anak usia dini telah banyak berkembang di masyarakat, baik yang ditumbuhkembangkan oleh instansi pemerintah maupun oleh masyarakat. Misalnya, Bina Keluarga Balita yang dikembangkan oleh BKKBN, Penitipan Anak oleh Depsos (dulu), TK oleh Depdiknas, TPA oleh Depag, dan Kelompok Bermain oleh masyarakat.

Secara umum, teknologi adalah berbagai keperluan serta sarana berbentuk aneka macam peralatan atau sistem yang berfungsi untuk memberikan kenyamanan serta kemudahan bagi manusia dalam kehidupan sehari-hari.

Elsa (2014:8) mengatakan Gadget merupakan sebuah inovasi baru dari teknologi terbaru dengan kemampuan yang lebih baik dan fitur terbaru yang memiliki tujuan maupun fungsi lebih praktis dan juga lebih berguna bagi manusia. Gadget merupakan suatu teknologi terbaru yang memiliki fungsi tertentu yang berguna bagi manusia untuk mempermudahkan komunikasi, yang menjadi kebutuhan yang harus ada dalam genggaman guna mempermudahkan komunikasi.

\section{METODOLOGI PENELITIAN}

Wawancara merupakan pertemuan dua orang atau leih untuk bertukar informasi dan ide melalu tanya jawab, sehingga dapat di kontruksikan makna dalam suatu topik tertentu

(Sugiono, 2012:317).

Wawancara Penelitian ini akan mengumpulkan informasi berupa hasil wawancara dengan pimpinan sekolah, dan wali murid di TK Elektrina tentang penggunaan atau dampak Gadget terhadap anak.

Observasi merupakan suatu aktivitas pencatatan fenomena yang dilakukan secara sistematis. Menurut (Nurkancana, 1933:35) observasi adalah suatu cara mengumpulkan data data dengan mengadakan pengamatan langsung terhadap suatu obek dalam suatu priode tertentu dan mengadakan pencatatan secara sistemetis tentang hal-hal tertentu yang diamati. Pengamatan langsung disini dimaksud berupa kegiata melihat, mendengar dengan alat indra lainnya. Dan dalam 
penelitian ini peneliti akan terlibat langsung (partisipatif) artinya dalam pengamatan ini peneliti akan terlibat dalam kegiatan orang yang menjadi sasaran penelitian. Untuk menyempurnakan aktivitas pengamatan partisipatif ini, peneliti harus mengikuti kegiatan keseharian yang dilakukan informan dalam waktu tertentu, memerhatikan apa yang terjadi, mendengarkan apa yang dikatakannya, mempertanyakan informasi yang menarik, dan mempelajari dokumen yang dimiliki Kegiatan observasi ini akan dilakukan secara intensif hingga memperoleh data dan gambaran tentang; letak geografis, keadaan lingkungan di TK Elektrina , serta dampak dari penggunaan Gadget terhadap perilaku sehari-hari anak.

Dokumentasi artinya barangbarang tertulis. Di dalam melaksanakan metode dokumentasi, peneliti menyelidiki benda-benda tertulis seperti buku-buku, majalah, dokumen, peraturan-peraturan, notulen rapat, catatan harian, dan sebagainya (Arikunto, 2010:201). Dalam penelitian ini teknik dokumentasi dapat dilakukan berupa
dataDokumentasi yang dilakukan dalam hal ini adalah segala dokumentasi yang berhubungan dengan gambar atau foto-foto Kegiatan di TK Elektrina.

\section{HASIL DAN PEMBAHASAN}

Berdasarkan dari hasil penelitian menunjukan kebanyakan Gadget yang diberikan para orang tua kepada anaknya adalah berdasarkan keinginan anaknya. Untuk tujuan tertentu seperti untuk mengenalkan teknologi lebih dini atau sekedar untuk membuat anaknya tidak bosan. Bagi orang tua yang seperti ini lebih beranggapan bahwa dengan Gadget anak usia dini dapat memperluas jaringan persahabatan mereka karena dapat dengan mudah dan cepat bergabung ke sosial media yang telah disediakan. Terkadang juga Gadget dapat dijadikan para orang tua untuk mengalihkan anak-anak agar tidak mengganggu pekerjaan oarang tuanya dan sampai menangis hal ini diperkuat oleh pernyataan pembantunya, sehingga para orang tua menyediakan fasilitas berupa Gadget untuk anaknya yang masih berusia dini dibandingkan dengan permainan edukatif lainnya. 
Hal ini tak lepas oleh berbagai aplikasi permainan yang terdapat pada Gadget yang tentunya lebih menarik perhatian anak-anak dibandingkan dengan permainan-permaian yang terdapat di lingkungan sekitarnya. Selain itu juga, orangtua meng"iya"kan bahwa saat anakanaknya bermain Gadget cenderung anak-anak ini diam di depan Gadget nya masing-masing tanpa mempedulikan dunia sekitarnya. Secara tidak sadar, anak-anak sudah mengalami ketergantungan menggunakan Gadget. Ketergantungan inilah yang menjadi salah satu dampak negatif yang sangat berpengaruh.

Dalam penggunaan Gadget kebanyakan anak lebih menggunakannya untuk bermain. Dari hal kecil tersebut, anak yang awalnya senang bermain dengan temannya dapat berubah dengan terbiasanya diberikan Gadget sebagai pengganti teman bermain. Kertergantungan terhadap Gadget pada anak disebabkan karena lamanya durasi dalam menggunakan Gadget . Bermain Gadget dengan durasi yang cukup panjang dan dilakukan setiap hari, bisa membuat anak berkembang ke arah pribadi yang antisosial. Dampak yang ditimbulkan dari hal itu sebenarnya adalah dapat membuat anak lebih bersikap individualis karena lama kelamaan menyebabkan lupa berkomunikasi dan berinteraksi terhadap lingkungan di sekitarnya.

Hal tersebut dapat menyebabkan interaksi sosial antara anak dengan masyarakat, lingkungan sekitar berkurang, bahkan semakin luntur. Seperti yang diketahui bahwa usia dini merupakan usia anak dapat mengasah kemampuan bersosialisasinya dengan baik dilingkungan sosial. Berdasarkn hasil penelitian ditemukan bahwa orangtua memahami Gadget sebagai sebuah alat yang merupakan hasil dari kemajuan teknologi. Alat-alat tersebut berupa smartphone, tab dan komputer. Kehadiran Gadget dalam kehidupan sehari-hari manusia, mengakibatkan dampak yang terdiri dari dampak positif dan dampak negatif. Dampak positif dari Gadget yang dirasakan oleh orangtua bagi kehidupan mereka dan perkembangan anak yaitu Gadget sangat membantu pekerjaan, dengan kata lain adanya Gadget bisa membuat pekerjaan jadi lebih mudah. Manfaat 
lain yang dirasakan oleh orangtua yaitu dalam hal perkembangan anaknya. Gadget dalam hal tersebut sangat membantu anak dalam meyelesaikan tugas-tugas sekolahnya dan membantu anak dalam hal mengembangkan kreatifitasnya melalui media game dan berbagai aplikasi yang ada di Gadget.

Selain dampak positif yang dimiliki oleh Gadget, orangtua juga menyebutkan tentang dampak negatif Gadget. Khusus bagi anak, dampak negatifnya yaitu efek kecanduan terhadap konten atau aplikasi yang terdapat dalam Gadget. Efek kecanduan tersebut mengakibatkan anak menjadi melupakan tugas utamanya sebagai pelajar. Gadget adalah sebuah istilah dalam bahasa Inggris yang mengartikan sebuah alat elektronik kecil dengan berbagai macam fungsi khusus.

Adapun beberapa dampak positif dari Gadget apabila orangtua bisa bijak dalam memberikanya kepada anak antara lain:

1) Kecanggihan fitur bahasa pada Gadget dapat meningkatkan kemampuan berbahasa anak.
2) Mendukung keingintahuan anak, dengan bimbingan orangtua anak dapat mengakses situs-situs yang ingin dipelajari anak di internet.

3) Merangsang anak untuk mengikuti perkembangan tekhnologi, sehingga anak tidak gagap tekhnologi di usianya.

4) Mendukung aspek akademis anak, dengan bantuan internet anak dapat mengakses informasiinformasi yang di butuhkan perihal pengtahuan yang diajarkan di sekolah.

5) Mengurangi tingkat steres dan menghilangkan rasa jenuh setelah belajar dengan sesekali bermain game.

Sedangkan dampak negatif Gadget terhadap tumbuh kembang anak diantaranya:

1) Mengganggu pertumbuhan otak anak

Pada usia 0-2 tahun, otak anak bertumbuh dengan cepat hingga dia berusia 21 tahun. Perkembangan otak anak sejak dini dipengaruhi oleh stimulasi lingkungan.

2) Stimulasi berlebih dari Gadget (hp, internet, tv, ipad, dll) pada 
otak anak yang sedang berkembang, dapat menyebabkan keterlambatan koginitif, gangguan dalam proses belajar, tantrum, meningkatkan sifat impulsif, serta menurunnya kemampuan anak untuk mandiri.

3) Tumbuh kembang yang lambat Bahaya penggunaan Gadget pada anak, juga membatasi gerak fisiknya. Yang membuat tumbuh kembang fisik anak menjadi terlambat. Paparan teknologi sejak dini juga memengaruhi kemampuan literasi dan prestasi akademik anak secara negatif.

4) Kurang tidur

$75 \%$ anak usia 9-10 tahun mengalami kurang tidur karena penggunaan teknologi tanpa pengawasan. Kekurangan tidur akan berdampak buruk pada nilai sekolah mereka, karena otak berkembang dengan baik saat tidur, dan anak butuh tidur yang cukup agar otaknya bisa berfungsi dengan baik.

5) Kelainan mental

Penelitian di Bristol University tahun 2010 mengungkapkan, bahaya penggunaan Gadget pada anak dapat meningkatkan risiko depresi, gangguan kecemasan, kurang atensi, autisme, kelainan bipolar, psikosis, dan perilaku bermasalah lainnya.

6) Sifat agresif

Konten di media yang bisa diakses anak, dapat menimbulkan sifat agresif pada anak. Kekerasan fisik dan seksual banyak tersebar di internet, dan jika tidak dilakukan pengawasan, anak bisa terpapar itu semua. Sehingga memicu timbulnya perilaku agresif dan cenderung menyerang orang lain pada anak.

7) Kecanduan

Ketika orangtua terlalu bergantung pada teknologi, mereka akan semakin jauh dari anak. Untuk mengisi kekosongan ikatan dengan orangtua, anak juga mulai mencari penghiburan dari Gadget, yang pada akhirnya membuat mereka kecanduan teknologi, dan tidak bisa lepas darinya.

8) Proses belajar yang tidak berkelanjutan

Penggunaan teknologi yang berlebihan pada anak, bisa 
membuat proses belajarnya tidak kontinyu. Karena teknologi ini membuat segalanya menjadi lebih mudah, sehingga otak anak tidak terasah, disebabkan kemudahan yang ditawarkan untuk mencari jalan pintas.

9) Menurunkan daya ingat dan konsentrasi anak karena tingginya kecepatan pada konten media yang menimbulkan perhatian. Sebagai orangtua yang hidup di zaman yang serba modern ini, kita harus bijak dalam menyikapi dan mengenalkan sarana tekhnologi kepada anak kita, agar supaya tidak terjadi hal-hal yang tidak diinginkan karena perkembangan tekhnologi

10) Gangguan pada mata akibat terlalu sering mata menatap layar Gadget.

Berkurangnya kemampuan bersosialisasi dengan orang lain.

Berdasarkan hasil penelitian, dijelaskan bahwa orangtua berkomunikasi dengan anaknya sebaiknya melalui beberapa cara yaitu:

1) Batasi Pemakaian Gadget Maksimal Dua Jam
Anak di atas dua tahun, hanya boleh berada di depan layar komputer, televisi atau Gadget maksimal selama dua jam setiap harinya. Waktu lain harus digunakan untuk bermain di luar rumah, berinteraksi dan berkomunikasi dengan anak lain agar bisa mengenali emosi.

2) Orangtua Mengedukasi Diri Soal Gadget

Sebelum memberikan Gadget ke anak, orangtua harus tahu dulu apa saja aplikasi yang ada di sana. Agar bisa menyaring konten yang sesuai dengan umur anak. Jangan jadi orangtua yang gaptek dan membiarkan anak terpapar konten negatif karena kita tidak mengerti.

3) Berikan Pengawasan

Dampingi anak ketika bermain Gadget. Kita sebagai orangtua juga bisa berdiskusi mengenai apa saja yang anak mainkan dan lakukan dengan Gadgetnya. Selain menjalin komunikasi, kita sebagai prangtua juga bisa sekaligus mengawasi paparan internet terhadap anak, perilaku anak di dunia maya. Bila sedang mengawasi anak, usahakan kita 
seagai orangtua jangan sibuk dengan Gadget sendiri.

4) Berikan Pengajaran Soal Perilaku di Internet

Jika kita sebagai orangtua melihat konten yang tidak sesuai dengan usia anak, beri dia pengertian bahwa konten tersebut tidak baik untuknya. Begitupun ketika dia melihat informasi yang kurang baik, ajak anak untuk mendiskusikannya. Jangan lupa mengingatkan anak agar tidak mudah memberikan identitas pribadi kepada orang yang tidak dikenal, atau aplikasi yang tidak jelas. Kita sebagai orangtua, sebaiknya jangan berlebihan memamerkan anak di media sosial. Hal ini demi mencegah kejahatan yang sering mengincar anak di dunia maya.

5) Biarkan Anak Bermain Tanpa Gadget

Dorong anak untuk bermain di dalam maupun di luar rumah tanpa Gadget. Tujuannya agar dia memiliki waktu berkualitas yang tidak dihabiskan untuk menatap layar Gadget. Selain bermanfaat untuk fisik anak, bermain tanpa
Gadget juga bisa merangsang tumbuh kembang motoriknya. Simpan Gadget kita saat anak akan bermain agar dia tidak tergoda untuk memegang perangkat elektronik tersebut.

6) Berikan Contoh Jangan hanya memberi larangan pada anak untuk tidak menggunakan Gadget, sementara orangtua selalu sibuk dengan Gadget. Ini akan memberi contoh yang buruk. Simpan Gadget ketika bermainlah bersama anak. Bercengkrama dengan mereka selama beberapa jam. Pekerjaan dan chat dari teman atau bos bisa menunggu. Namun anak tidak akan menjadi anak kecil selamanya. Berikan ia teladan, bahwa ada hal-hal yang lebih penting di dunia ini dibandingkan Gadget. Yakni kebersamaan dengan keluarga tercinta.

7) Tetapkan Waktu Dan Tempat Bebas Gadget Di Rumah

Cara terakhir untuk mencegah anak kecanduan Gadget, dengan menetapkan aturan area dan waktu bebas Gadget di rumah. Misalnya di meja makan ketika 
sedang makan bersama. Baik anak-anak maupun orangtua tidak ada yang boleh memegang Gadget saat makan. Anda juga harus membiasakan anak untuk tidak membawa perangkat elektronik apapun ke dalam kamar. Selain menghindari kecanduan Gadget, juga mendorong anak memiliki waktu tidur yang lebih baik dan teratur.

Dari pemahasan tersebut bisa ditemukan tentang pentingnya sikap saling menghargai dalam berkomunikasi dalam keluarga. Hal ini sudah dipraktikkan oleh keluarga. Hal lain yang sudah dipraktikkan oleh keluarga (orangtua) terkait cara berkomunikasi, memberikan pemahaman tentang Gadget kepada anak yaitu berikan pengajaran soal perilaku di internet, jika anda melihat konten yang tidak sesuai dengan usia anak, beri anak pengertian bahwa konten tersebut tidak baik untuk si anak. Pada poin ini, dijelaskan bahwa setiap anggota keluarga memiliki peran masing-masing. Masing-masing peran yang dimainkan dalam keluarga memiliki tanggung jawabnya masingmasing. Dengan setiap anggota keluarga memahami perannya dan bertanggung jawab atas peran tersebut, agar keseimbangan dalam keluarga terjamin.

Hambatan yang dirasakan orangtua dalam berkomunikasi kepada anak terkait upaya mencegah dampak negatif Gadget. Berdasarkan hasil penelitian di atas, dikatakan bahwa ada beberapa hambatan yang dirasakan oleh orangtua dalam berkomunikasi kepada anak terkait upaya mencegah dampak negatif Gadget. Hambatan tersebut antara lain:

1) Kesibukan masing-masing anggota keluarga.

2) Emosi yang meningkat ketika anak menggunakan Gadget terlalu lama melebihi waktu yang disepakati.

3) Kurang pengetahuan tentang penggunaan Gadget yang baik.

Berdasarkan hasil penelitian diatas, dikatakan bahwa keluarga melakukan usaha dalam mencegah dampak negatif Gadget terhadap anak. Usaha tersebut yaitu memberikan pengetahuan agama kepada anak dan menyemangati anak agar mendengarkan orangtua dengan 
memberi hadiah saat anak menurut dan mentaati kesepakatan dan hukuman saat anak yang dapat digunakan oleh orangtua dalam mencegah dampak negatif Gadget, antara lain:

Orangtua harus mengetahui rating dari game atau acara televisi yang di lihat oleh anak. Cari tahu apakah media tersebut aman dan sesuai dengan batasan usia anak, tidak memasang perangkat elektronik di dalam kamar anak. Buat aturan, aturan dalam hal ini yaitu tentang batasan waktu penggunaan Gadget buat anak awasi media yang dilihat oleh anak.

Perkembangan teknologi dan komunikasi saat ini sangat pesat. Pengembangan teknologi dan komunikasi ini memberikan dampak yang sangat besar terhadap dunia pendidikan, tidak hanya orang dewasa yang mengenal teknologi dan komunikasi canggih ini, tetapi juga pengaruh terhadap perkembangan dan pendidikan anak usia dini. Gadget merupakan alat berukuran mini dengan banyak kegunaan yang dapat di peroleh didalamnya. Kemudahan dalam mengakses berbagai informasi dan hiburan telah tersaji dalam bentuk online dan offline. Sebenarnya, Gadget ditunjukan untuk orang-orang yang memiliki kepentingan dalam hal bisnis, perkuliahan dan pekantoran. Namun pengguna Gadget sering kali disalahgunakan oleh sebagian pihak, seperti orangtua secara instan memberikan fasilitas Gadget untuk media dalam mendidik anaknya yang masih berusia dini.

Anak usia dini adalah sosok individu sebagai mahluk sosial yang sedang mengalami peroses perkembangan yang sangat fundamental bagi kehidupan selanjutnya dan memiliki sejumlah karekteristik tertentu. Anak usia dini adalah suatu organisme yang merupakan satu kesatuan jasmani dan rohani yang utuh dengan segalah struktur dan perangkat biologis dan fisikologisnya sehingga menjadi sosok yang unik.

1) Intensitas Penggunaan Gadget Pada Anak Usia Dini

Saat Anak usia di bawah 5 tahun, boleh-boleh saja diberi Gadget . Tapi harus diperhatikan orang tua dalam durasi pemakaian gadget yang di berikan kepada anaknya, misalnya hari Sabtu atau Minggu dengan durasi 
tidak lebih dari 30 sampai dengan 75 menit dalam sehari . Lewat dari itu, ia harus tetap berinteraksi dengan orang lain dan belajar.

Terlihat jelas bahwa penggunaan Gadget memang harus memiliki batasan dan kriteria tertentu dalam pemakaian Gadget untuk menghindari tingkat kecanduan anak dalam menggunakan Gadget, Bentuk penggunaan Gadget pada anak dapat diklasifikasikan pada tingkatan tinggi, sedang, dan rendah. Kategori rendah apabila penggunaan Gadget hanya saat waktu senggang.

Untuk itu perlu adanya kedisiplinan dan batasan yang dilakukan orang tua pada saat anak usia dini menggunakan Gadget, karena pemakaian Gadget yang berkelanjutan dan tidak memiliki batas waktu dapat menimbulkan dampak buruk kecanduan Gadget sejak dini. Gadget memiliki banyak manfaat apalagi digunakan dengan cara yang benar dan semestinya diperbolehkan orang tua mengenalkan Gadget pada anak usia dini memang perlu tetapi harus diingat terdapat dampak positif dan dampak negatif pada Gadget tersebut.
Tabel Durasi dan Intentitas Penggunaan Gadget Pada Anak Usia Dini

\begin{tabular}{|c|c|c|}
\hline Kategori & Durasi & Intensitas \\
\hline Tinggi & $\begin{array}{c}75-120 \\
\text { menit }\end{array}$ & $\begin{array}{c}\text { Lebih dari tiga } \\
\text { kali perhari }\end{array}$ \\
\hline Sedang & $\begin{array}{c}40-60 \\
\text { menit }\end{array}$ & $\begin{array}{c}2-3 \text { kali } \\
\text { perhari }\end{array}$ \\
\hline Rendah & $\begin{array}{c}5-30 \\
\text { menit }\end{array}$ & $\begin{array}{c}\text { Maksimal 1 } \\
\text { sampai kali } \\
\text { perhari }\end{array}$ \\
\hline
\end{tabular}

Berdasarkan uraian-uraian tersebut terlihat jelas bahwa penggunaan Gadget memang harus memiliki batasan-batasan dan kriteria tertentu dalam pemakaian Gadget untuk menghindari tingkat kecanduan anak dalam menggunakan Gadget.

\section{KESIMPULAN DAN SARAN}

Berdasarkan hasil penelitian dan pembahasan mengenai komunikasi orangtua terhadap anak dalam mencegah dampak negatif Gadget, bisa diambil kesimpulan tentang pengaruh Gadget terhadap akhlak anak dalam studi kasus di TK Elektrina Kertapati Palembang, dapat diambil kesimpulan guna menjawab pertanyaan masalah sebagai berikut: Dampak dari tekhnologi khususnya Gadget terhadap pembentukan kepribadian atau akhlak anak antara lain anak akan menjadi lebih pemalas, kurangnya rasa percaya diri pada anak, 
berkurangnya kemampuan berkomunikasi anak, anak akan lebih tertutup, ketergantungan anak untuk terus bermain Gadget dan dampak negatif yang paling berbahaya adalah anak dengan bebas dapat mengakses situs-situs dewasa di internet yang dapat merusak moral anak.

\section{Dalam} mengatasi ketergantungan Gadget, anak dan orangtua dapat memberikan kesibukan kegiatan kepada anaknya, mengganti Gadget dengan alat bermain tradisional yang syarat akan nilai edukasi, mengajak anak untuk anak bermain di alam alam terbuka untuk bermain dan berkomunikasi dengan anaknya. Sebagai orangtua yang cerdas, orangtua harus memberikan batasan waktu kepada anaknya untuk bermain Gadget, selalu mendampingi anak saat bermain Gadget, memberikan pengertian tentang dampak positif dan negatif tekhnologi sehingga anak tahu mana yang baik dan yang buruk dan orangtua harus mengawasi kegiatan anak setiap harinya.

Orangtua merupakan faktor utama penentu moral dan akhlak anak di masa depan, kepribadian anak merupakan cerminan bagaimana orangtua tersebut mendidik dan mengajari anaknya. Terlebih lagi kita hidup di zaman yang serba modern sehingga tantangan yang diterima orangtua dalam mendidik anaknya semakin besar.

Sebagai orangtua yang baik alangkah baiknya jika orangtua meluangkan waktunya di sela-sela kesibukan dalam bekerja untuk memantau kegiatan anak atau hanya sekedar untuk menemaninya bermain dan berkomunikasi sehingga anak tidak merasa kesepian dan kurang perhatian dari orangtua. Pesatnya perkembangan tekhnologi mengharuskan setiap orangtua untuk memberikan bimbingan dan arahan kepada anaknya tentang dampak baik dan buruk dalam penggunaan sarana tekhnologi, sehingga anak paham, mengerti dan bijak dalam menggunakan Gadget.

\section{DAFTAR PUSTAKA}

Arikunto, Suharsimi (2010). Prosedur Penelitian, Jakarta: Rineka Cipta.

Berita Jakarta. http://www.beritajakarta.com Siswa Kelas 3 SD Diduga Sodomi 5 Bocah Di Jakut. Di 
Akses pada 5 januari 2019 waktu 19:15 WIB

Denak Sintia Rahmawati (2013), Skripsi "analisis penggunaan Gadget terhadap akhlak anak ( studi kasus di sd $n 01$ kebonharjo, klaten) analysis of Gadget usage on children's morals (case study at sd $n 01$ kebonharjo, klaten)" universitas islam indonesia yogyakarta

Elsa Vindi (2014), Studi Korelasional Pengaruh Smartphone Terhadap Interaksi Sosial Remaja Dikalangan Siswa Sma Harapan 1 Medan).

Irianto.

http://www.saibumi.com.

(2015).

Pencabulan Anak SD di pringsewu. Di unduh pada 8 Februari 2019 waktu 14:15 WIB

Margono, S. 2010. Metodologi penelitianpendidikan.Jakarta: Airlangga

Moleong, (2017) Metodologi Penelitian Kualitatif, Bandung: Remaja Rosdakarya

Monica

Erisanti, (2013)http://www.kompas.com "Jangan Tenangkan Anak Rewel dengan "Gadget", di akses pada hari Selasa, 3 Februari 2019 waktu 17:15 WIB

Mubashiroh,(2013),Penggunaan dan Dampak Gadget Pada Anak. Skripsi Semarang: Universitas Negeri Semarang. di akses pada hari Selasa,3 Februari 2019 waktu 17:15 WIB
Nurkencana. 1993. Pemahaman individu1. Jakarta: Erlangga

Novita Sari dan Nurul. (2016). http://jurnalilmiahtp Gadget Pengguna Dan Dampak negatif Pada Anak.

Octaviani, (2013) (Menelisik Pengaruh Penggunaan Aplikasi Gadget Terhadap Perkembangan Psikologis Anak Usia Dini),Skripsi. Semarang: Universitas Negeri Semarang.

Sanjaya Wina,(2013) Penelitian Pendidikan, Jakarta:Kencana Prenada.

Sugiyono,(2016)Metode Penelitian Pendidikan, Bandung: Alfabeta.

Sugiyono.(2012). Metode Penelitian Pendidikan (Pendekatan Kuantitatif, Kualitatif dan $R$ $\& D)$. Bandung: Alfabeta.

Wahyu Novitasari,'UNS: Dampak Penggunaan Gadget Terhadap Interaksi Sosial Anak Usia 54 Tahun, (Vol 05 No.03, 2016), h. $182-186$

Yin Robert, (2012) Studi Kasus Desain Dan Metode, Jakarta: Rajawali Pers.

Yuliani Sujiono, (2013) Konsep Dasar Pendidikan Anak Usia Dini, Jakarta:Indek 